\title{
Kesan Penambahan Kepingan Nanozarah Grafin terhadap Sifat Mekanik dan Terma Hibrid Komposit Serabut Sansevieria-Getah Asli-Polietilena Berketumpatan Tinggi (Effects of Addition Graphene Nanoplatlet on the Mechanical Properties and Thermal Hybrid Composite Fibre Sansevieria Natural Rubber-High Density Polyethylene)
}

\author{
NURZAM EZDIANI ZAKARIA, ISHAK AHMAD, WAN NAZRI WAN BUSU, \\ KHAIRUNNIZAH HAZILA KHALID \& AZIZAH BAHARUM*
}

\begin{abstract}
ABSTRAK
Kajian ini dilakukan untuk mengkaji kesan penghibridan kepingan nanozarah grafin (GNP) ke atas sifat mekanik, morfologi dan terma komposit Sansevieria trifasciata-getah asli-polietilena ketumpatan tinggi (STF-NR-HDPE). Pemprosesan penghibridan komposit STF-NR-HDPE dan GNP dilakukan dengan menggunakan mesin pengadun dalaman. Tahap pengisian sebanyak $20 \%$ bt. STF ke atas matriks (NR/HDPE) telah dilakukan dalam kajian ini dengan variasi GNP yang digunakan adalah antara 1-10\% bt. Adunan komposit yang terhasil ditekan dengan mesin penekan panas untuk mendapatkan sampel ujian berketebalan $1 \mathrm{~mm}$ dan $3 \mathrm{~mm}$. Sampel dinilai melalui ujian tegangan, ujian hentaman Izod, pembelauan sinar-X (XRD) dan kalorimetri pengimbasan berbeza (DSC). Kajian morfologi pula dijalankan dengan menggunakan mikroskop elektron pengimbas pelepasan medan (FESEM). Keputusan menunjukkan bahawa nilai kekuatan regangan dan kekuatan hentaman komposit menunjukkan sedikit penurunan bacaan pada permulaan penambahan amaun GNP tetapi bacaan kebanyakan komposisi kemudiannya menunjukkan peningkatan selepas $5 \%$ bt. tahap pengisian dan ke atas. Modulus tegangan pula secara umumnya menunjukkan peningkatan bacaan dengan penambahan pengisi. Analisis terma dengan menggunakan alat DSC tidak menunjukkan perubahan aliran graf yang ketara terhadap kelakuan terma bahan. Ini kerana STF adalah bahan yang mempunyai kestabilan terma yang baik.
\end{abstract}

Kata kunci: Kepingan nanozarah grafin; komposit hibrid; serabut semula jadi; sifat mekanik

\section{ABSTRACT}

This research was done to study the effects of graphene nanoplatlet (GNP) hybridization on the mechanical, morphological and thermal properties of Sansevieria trifasciata-natural rubber-high density polyethylene (STF-NR-HDPE) composite. Processing of STF-NR-HDPE with modification of GNP was done by using an internal mixer. Filler loading of $20 \mathrm{wt} . \%$ STF into the matrix (NR/HDPE) was introduced in this study with variation of GNP composition used was around 1-10 wt. \%. Composite blends obtained were pressed with a hot-press machine to produce samples with $1 \mathrm{~mm}$ and 3 mm of thickness. Samples were evaluated via tensile test, Izod impact test, X-Ray Diffraction (XRD) and differential scanning calorimeter (DSC). Morphological study was done by using a field emission scanning electron microscope (FESEM). The results showed that tensile strength and impact strength had decreased at the early stage of GNP addition but the values keep increasing after more than $5 \mathrm{wt}$ \% of GNP were added to the system. Generally, tensile modulus showed an increasing trend with the increment of filler loading. Thermal analysis with DSC did not show any obvious trend towards materials' thermal behavior. This is due to the good thermal stability characteristic of STF.

Keywords: Graphene nanoplatlet; hybrid composites; mechanical properties; natural fiber

\section{PENGENALAN}

Komposit terhibrid ialah komposit yang terhasil apabila dua atau lebih pengisi/gentian diperkuat yang telah ditetapkan skala dan geometrinya, digabungkan bersama matriks untuk menghasilkan bahan optimum yang boleh memenuhi sesuatu keperluan dalam bidang kejuruteraan (Sameer et al. 2015; Sathishkumar et al. 2014). Komposit terhibrid biasanya melibatkan gabungan beberapa bahan yang diperlukan untuk memperbaiki kekurangan sesuatu komponen bahan lain atau untuk memberikan nilai tambah kepada aplikasi sesuatu bahan yang terhasil. Fasa penguatan biasanya terdiri daripada bahan berbentuk serabut/gentian, partikel ataupun kepingan manakala bahan bagi fasa matriks pula bersifat berterusan. Menurut Sathiskumar et al. (2014), penghibridan serabut/gentian dilakukan untuk menambahbaik sifat mekanik, terma dan sifat redaman bahan berbanding dengan komposit yang diperkuat oleh satu jenis serabut/gentian sahaja. Komposit hibrid diperkuat serabut/gentian biasanya mengandungi dua atau lebih jenis pengisi dalam sistem matriks tersebut. Komposit terhibrid yang menggabungkan bahan penguat yang bersesuaian mampu memberikan bahan yang mempunyai sifat fizik dan mekanik yang lebih mantap untuk aplikasi yang lebih meluas (Nurul Hidayah 2018). 
Ketidakstabilan harga minyak mentah dunia telah memberi kesan kepada kenaikan harga bahan mentah dalam industri plastik. Penyelidikan tentang penambahan pelbagai jenis pengisi ke dalam plastik semakin giat dijalankan. Penggunaan pengisi semula jadi berasaskan bahan berlignoselulosa adalah salah satu cara untuk mengurangkan penggunaan plastik dalam komposit, mengurangkan kos pemprosesan dan juga untuk pengubahsuaian sifat mekanik bahan. Selain itu, penggunaan pengisi semula jadi berupaya menyumbang kepada penghasilan bahan dengan ketumpatan yang lebih rendah, ringan, mesra alam, kurang merbahaya, tidak kasar, boleh dikitar semula, nilai modulus yang lebih tinggi, mudah dimodifikasi secara kimia dan juga boleh diperoleh pada harga yang lebih rendah (Faruk et al. 2012; Kanimozhi 2011; Nurul Hidayah 2018; Sreenivasan et al. 2011). Penambahan getah asli ke dalam matriks juga dapat membantu ke arah pemprosesan bahan yang lebih baik. Ini kerana struktur polimer termoplastik dan getah yang hampir sama, keserasian bahan dan juga interaksi antara fasa yang baik, mendorong kepada sifat mekanik yang lebih baik (Hanafi 2001).

Kajian dan penggunaan pelbagai jenis pengisi berlignoselulosa seperti kenaf, daun nanas, tandan kelapa sawit dan sekam padi telah banyak dijalankan di Malaysia. Penerokaan tentang potensi penggunaan bahan berlignoselulosa yang baru akan dapat memberikan persaingan kepada sumber sedia ada. Tambahan pula pokok Sansevieria trifsciata (ST) ini mempunyai pelbagai potensi yang belum diterokai secara menyeluruh. Pokok ST biasanya digunakan sebagai pokok hiasan sama ada di rumah ataupun di taman. Pokok ini dikatakan boleh menyahkan toksin yang terdapat di udara. Nama biasa bagi ST adalah lidah ular, lidah jin, lidah mak mertua, pokok ular dan juga bow string hemp. Pokok ini adalah daripada jenis kategori pokok herba dengan 2-6 helai daun dikeluarkan oleh setiap umbinya. Daunnya yang berbentuk runcing boleh memanjang antara 0.3-1 m apabila mencapai tempoh matang. Daun yang panjang ini mampu membekalkan sumber serabut yang banyak dan mempunyai banyak potensi yang perlu dikaji. Kajian oleh Ramainaiah et al. (2013) menunjukkan serabut Sansevieria mempunyai sifat mekanik dan juga sifat penyalutan terma yang baik. Ia juga memberikan komposisi kimia yang menyamai daun nanas dengan jumlah lignin yang kurang berbanding daun nanas. Serabut ST yang dikaji oleh Kanimozhi (2011) juga memberikan bacaan nisbah aspek (panjang per diameter) yang tinggi berbanding dengan kebanyakan serabut semula jadi yang lain.

Namun begitu, interaksi antara bahan sangat mempengaruhi sifat komposit yang dihasilkan. Oleh itu, satu jenis pengisi di dalam matriks getah atau termoplastik sahaja tidak dapat memenuhi keperluan untuk menghasilkan komposit termaju yang baik. Gabungan beberapa jenis pengisi berasaskan karbon adalah salah satu cara yang baik untuk menseimbangkan kos dan sifat komposit yang akan dihasilkan (Valentini et al. 2016). Penambahan pengisi bersaiz nano juga adalah merupakan satu cara untuk memperbaiki sifat komposit (Kang et al. 2017; Sheshmani et al. 2013).

Ledakan penyelidikan membabitkan grafin bermula sekitar tahun 2004 (Idumah \& Hassan 2016) (Muhammad Razlan et al. 2017). Semenjak itu, semakin ramai penyelidik dari seluruh dunia yang telah mula giat menjalankan penyelidikan lanjutan mengenai sifat grafin dan aplikasi bahan tersebut. Kajian terhadap grafin dan bahan-bahan terbitannya mula mendapat perhatian kerana ia berfungsi sebagai bahan tambah kepada polimer matriks yang berkemampuan untuk memperbaiki sifatsifat fizikokimia dan mekanik bahan tersebut (He et al. 2017). Grafin ialah sejenis partikel karbon berbentuk satu lapisan yang terdiri daripada atom-atom karbon terhibrid $\mathrm{sp}^{2}$ selari secara heksagon dalam struktur planar dan tersusun padat dalam struktur kekisi berbentuk sarang lebah, dengan ciri-ciri serta potensi yang sangat bagus sebagai pengisi nanokomposit (Frasca et al. 2015; Geng et al. 2009; Kumar \& Xavior 2017; Nor Nabilla 2018). Struktur dengan beberapa lapisan atom karbon ini juga dinamakan kepingan nanozarah grafin (GNP). GNP adalah pengisi bersaiz nano yang bersifat multifungsi kerana dapat memperbaiki sifat terma, mekanik, elektrik dan juga sifat rintangan gas dengan hanya jumlah kemasukan pengisi yang sedikit pada kos yang rendah (Idumah \& Hassan 2016) (Sheshmani et al. 2013).

Kajian terdahulu telah banyak dijalankan untuk mengkaji kesan penambahan pengisi ke atas berbagai jenis polimer. Namun begitu, kajian kesan penambahan GNP ke atas komposit berasaskan kayu dan serabut berlignoselulosa masih belum begitu luas dijalankan. Objektif kajian ini adalah untuk mengkaji kesan penambahan GNP ke atas komposit serabut Sansevieria trifasciata-getah asli-polietilena berketumpatan tinggi dengan mengambil kira faktor tahap pengisian GNP di dalam komposit tersebut. Gabungan dua pengisi bersaiz mikro dan nano diharapkan dapat saling memperbaiki kekurangan sifat pengisi antara satu sama lain dan mampu menghasilkan bahan yang lebih baik serta berpotensi untuk diaplikasikan sebagai bahan pembungkusan dan bahan berteknologi hijau. Modifikasi terhadap elastomer dengan menggunakan pengisi bersaiz nano yang berasaskan grafin juga dilihat dapat mempelbagaikan lagi aplikasi bahan komposit terbabit terutamanya untuk kegunaan bahan dalam cuaca yang ekstrim dan juga bagi mengurangkan kos penyelenggaraan berbanding elastomer tradisional (He et al. 2017).

\section{BAHAN DAN KAEDAH PENYELIDIKAN}

Resin polietilena berketumpatan tinggi (gred Etilenas HD5301AA) telah dibeli daripada Syarikat Polyethylene (M) Sdn. Bhd. Getah asli (gred SMR-L) pula dibekalkan oleh Syarikat Chemolab Supplies. GNP (gred KNG-150) yang berketebalan 5-15 nm, diameter $5 \mu \mathrm{m}$ dan berketumpatan $2.25 \mathrm{~g} / \mathrm{cm}^{3}$ telah dibekalkan oleh KNANO. Daun Sansevieria trifasciata pula dituai daripada pokok-pokok yang berusia 
melebihi 2 tahun di sekitar Lembah Klang. Daun-daun tersebut kemudiannya telah dibasuh dan dipotong dengan menggunakan mesin pemotong (Emura, Japan). Daun yang telah dipotong kemudiannya telah dikeringkan dengan mesin pengering pada suhu $60^{\circ} \mathrm{C}$ selama 5 jam dan dikisar dengan mesin pengisar untuk menghasilkan serabut dengan saiz yang lebih kecil. Serabut tersebut kemudiannya telah diayak kepada saiz $1 \mathrm{~mm}, 500 \mu \mathrm{m}, 250 \mu \mathrm{m}$ dan $125 \mu \mathrm{m}$ dengan menggunakan mesin pengayak (Retsch, Jerman). Serabut bersaiz $125 \mu \mathrm{m}$ telah digunakan di dalam kajian ini kerana berdasarkan kajian lepas oleh penulis, komposit berpengisi STF yang bersaiz $125 \mu \mathrm{m}$ telah memberikan keputusan yang paling optimum berbanding saiz yang lain (Nurzam Ezdiani et al. 2018).

Pengadunan komposit dilakukan dengan menggunakan mesin pengadun dalaman (Brabender W50EHT, Jerman). Parameter pemprosesan yang digunakan adalah $135^{\circ} \mathrm{C}$ untuk suhu dengan kelajuan rotor pada $55 \mathrm{rpm}$ selama 15 min. Parameter ini adalah hasil uji kaji terdahulu yang telah dilakukan untuk mencari parameter pemprosesan yang optimum (Nurzam Ezdiani et al. 2018). Komposisi NR/HDPE yang digunakan di dalam kajian ini ialah 40/60 manakala tahap pengisian STF yang digunakan ialah sebanyak 10-30\% bt. Jumlah kemasukan GNP pula ialah antara 1-10\% bt. Menurut Gao et al. (2017), daripada analisis SEM dan XRD, keputusan menunjukkan bahawa GNP dapat disebarkan di dalam polimer dengan baik sehingga $10 \%$ bt. tahap pengisian. Oleh itu, komposisi GNP dalam kajian ini telah divariasikan antara 1-10\% bt. Komposit yang terhasil kemudiannya telah ditekan dengan menggunakan mesin penekan panas (Labtech, Sweeden) untuk menghasilkan sampel berketebalan $1 \mathrm{~mm}$ dan $3 \mathrm{~mm}$. Suhu yang digunakan ialah $145^{\circ} \mathrm{C}$ dengan keseluruhan masa adalah selama $12 \mathrm{~min}$.

\section{UJIAN TEGANGAN}

Ujian tegangan dilakukan mengikut ASTM D412 dengan mengunakan Mesin Pengujian Universal Instron (model 5567, United Kingdom). Sampel berbentuk dumb-bell yang berketebalan $1 \mathrm{~mm}$ dipotong daripada kepingan komposit yang telah ditekan dengan menggunakan mesin pemotong. Kelajuan yang digunakan ialah $50 \mathrm{~mm} / \mathrm{min}$ pada suhu $25 \pm 3^{\circ} \mathrm{C}$. Sebanyak tujuh spesimen telah digunakan dan nilai purata telah diambil sebagai bacaan.

\section{UJIAN HENTAMAN}

Ujian hentaman Izod dijalankan mengikut ASTM D570 dengan menggunakan mesin pengujian hentaman (model 104, USA). Spesimen bersaiz $64 \times 12.7 \times 3 \mathrm{~mm}$ telah dipotong dengan menggunakan pemotong Hollow Die Punch. Sampel dengan takukan sedalam $1 \mathrm{~mm}$ diletakkan pada pemegang sampel pada mesin pengujian hentaman dengan permukaan yang bertakuk menghadap kawasan yang akan dihentam oleh pendulum. Ujian dijalankan pada suhu $25 \pm 3^{\circ} \mathrm{C}$. Lima spesimen telah diuji dan bacaan purata diambil.

\section{ANALISIS DSC}

Analisis terma dilakukan ke atas sampel dengan menggunakan mesin kalorimeter imbasan perbezaan (DSC) jenis Mettler Toledo (model 823e, USA). DSC digunakan untuk mengukur tahap kekristalan, suhu peralihan kaca dan takat lebur $\left(\mathrm{T}_{\mathrm{c}}, \mathrm{T}_{\mathrm{g}}\right.$ dan $\left.\mathrm{T}_{\mathrm{m}}\right)$ komposit STF-NR-HDPE termodifikasi dengan GNP. Sebanyak $12 \mathrm{mg}$ sampel diletakkan dalam ceper aluminium dan dipateri rapat. Setiap sampel dipanaskan selama 1 minit pada suhu $200^{\circ} \mathrm{C}$, kemudian disejukkan pada kadar $10^{\circ} \mathrm{C}$ per minit sehingga suhu mencecah $-40^{\circ} \mathrm{C}$ dan kemudiannya kembali dipanaskan daripada suhu $-40^{\circ} \mathrm{C}$ sehingga mencapai suhu $200^{\circ} \mathrm{C}$ pada kadar $10^{\circ} \mathrm{C} \mathrm{min}^{-1}$.

\section{ANALISIS PEMBELAUAN SINAR-X (XRD)}

Analisis XRD dilakukan dengan menggunakan mesin Bruker Advance (model D8, United Kingdom). Keamatan belauan daripada sumber radiasi $\mathrm{Cu} \mathrm{K \alpha}(0.154 \mathrm{~nm}, 40 \mathrm{kV}$ dan $40 \mathrm{~mA}$ ) diukur antara sudut $5^{\circ}$ hingga $85^{\circ}$.

\section{KAJIAN MORFOLOGI}

Kajian morfologi dijalankan dengan menggunakan mikroskop elektron pengimbas pelepasan medan (FESEM) jenis Zeiss Supra (55VP, Jerman). Permukaan patah sampel yang telah melalui ujian hentaman Izod telah digunakan dalam kajian ini. Sampel akan disalut dengan platinum dengan menggunakan penyadur platinum bagi membenarkan elektron menembusi bahan.

\section{KEPUTUSAN DAN PERBINCANGAN}

Rajah 1 menunjukkan keputusan ujian tegangan yang dijalankan ke atas sampel bagi mengukur kekuatan bahan. Kekuatan tegangan adalah ciri penting untuk menilai bagaimana bahan yang diuji bertindak terhadap daya tegasan yang dikenakan ke atasnya, terutamanya bagi bahan berpengisi serabut semula jadi (Noor Intan et al. 2018). Nilai kekuatan daya tegasan bagi setiap komposisi hibrid STF-GNP diplotkan melawan penambahan amaun kemasukan GNP. Nilai tegasan menunjukkan penurunan pada komposisi $1 \%$ GNP namun terus meningkat apabila jumlah kemasukan GNP ditingkatkan. Penggunaan pengisi berselulosa biasanya akan merendahkan nilai tegasan bahan. Namun begitu, peningkatan nilai tegasan dapat dicapai dengan penambahan GNP ke dalam komposit STF-NR-HDPE. Ini kerana zarah GNP dapat menampung lebih tekanan apabila daya tegasan dikenakan ke atas bahan (Sheshmani et al. 2013). Penambahan 20\% pengisi menghasilkan keputusan yang lebih stabil dengan nilai tegasan didapati semakin meningkat dengan penambahan kuantiti GNP. Daripada nilai tegasan yang diperoleh, komposisi $7 \%$ bt. GNP telah memberikan nilai yang paling optimum bagi ujian tegangan bahan yang dilakukan.

Rajah 2 pula menunjukkan keputusan ujian tegangan ke atas kekuatan modulus bahan. Modulus tegangan adalah penting untuk mengkaji kekakuan dan keliatan bahan. 


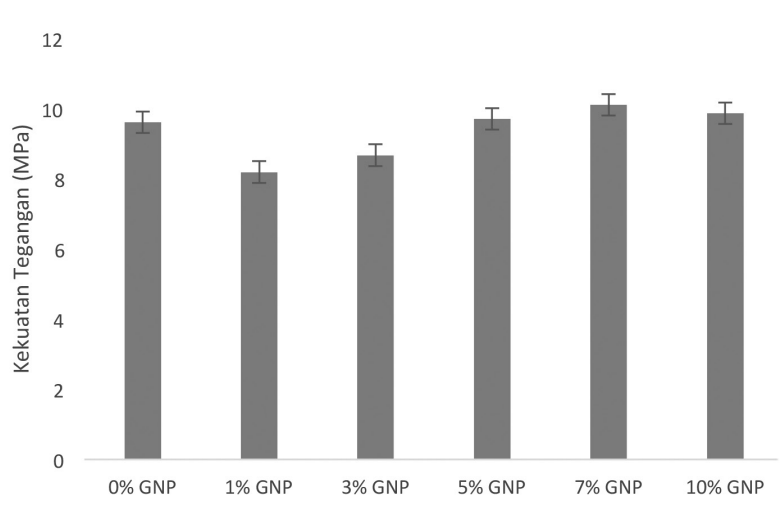

RAJAH 1. Nilai kekuatan tegangan bahan melawan peratusan komposisi GNP

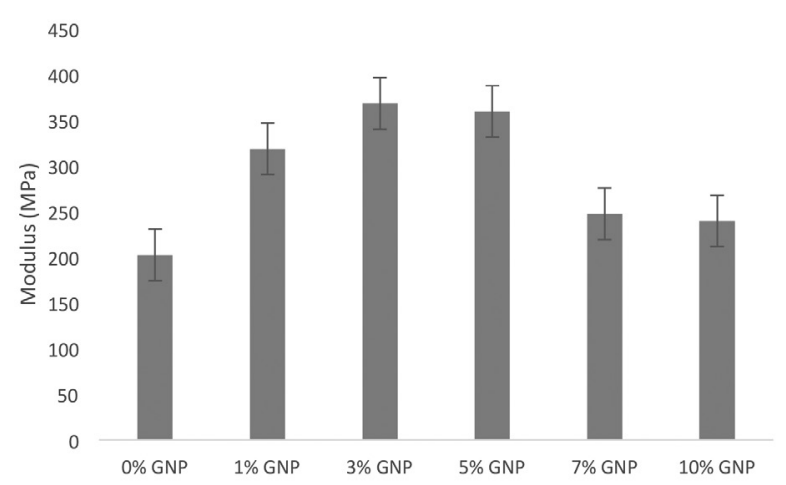

RAJAH 2. Nilai kekuatan modulus tegangan bahan melawan peratusan komposisi GNP

Keputusan modulus Young merujuk kepada kekukuhan nanokomposit polimer yang dihasilkan. Peningkatan bacaan modulus Young menunjukkan bahawa jika sesuatu komposit itu semakin kukuh maka lebih daya tegasan diperlukan untuk menghasilkan terikan bahan. Nilai modulus tegangan didapati meningkat dengan penambahan jumlah GNP sebanyak $1 \%$ sehingga $5 \%$ di dalam pengisi. Pada komposisi $7 \%$ dan $10 \%$ GNP, nilai modulus kembali menurun. Umumnya, penambahan pengisi bersaiz nano akan meningkatkan kekuatan tegangan dan nilai modulus komposit. Namun begitu, amaun pengisi, jenis pengisi, serakan pengisi di dalam matriks serta interaksi antara pengisi-pengisi dan pengisi-matriks juga merupakan faktor penting yang menyumbang kepada peningkatan nilai regangan dan modulus komposit. Nilai modulus yang paling tinggi diperoleh pada komposisi 3\% GNP. Menurut Frasca et al. (2015), nilai modulus yang paling tinggi juga dicapai pada komposisi grafin sebanyak 3\% di dalam adunan elastomer.

Rajah 3 pula menunjukkan keputusan ujian kekuatan hentaman yang dilakukan ke atas komposit yang terhasil. Penambahan pengisi berlignoselulosa akan meningkatkan kerapuhan bahan. Oleh itu, nilai hentaman akan menurun dengan penambahan komposisi STF. Penambahan GNP dijangkakan dapat meningkatkan nilai kekuatan hentaman komposit hibrid. Namun begitu, graf menunjukkan penambahan GNP ke atas komposit STF/NR/ HDPE tidak begitu membantu meningkatkan nilai kekuatan hentaman bahan. Peningkatan nilai kekuatan hentaman diperhatikan pada tahap penambahan GNP sekitar 3-5\% sebelum menunjukkan penurunan. Kajian terdahulu juga menunjukkan peningkatan nilai kekuatan hentaman hanya dicapai pada kuantiti GNP yang sedikit (Sheshmani et al. 2013). Ini kerana, penambahan amaun GNP yang banyak ke dalam komposit akan menyebabkan partikel GNP tidak dapat disebarkan dengan baik. Kandungan GNP yang terlalu tinggi menyebabkan GNP tersusun antara satu sama lain dengan lebih mudah dan membentuk gumpalan atau timbunan disebabkan oleh tenaga permukaan yang tinggi serta nisbah aspek yang besar (Gao et al. 2017). Ini menyebabkan berkurangnya jumlah perlekatan antara partikel GNP dan komposit dan seterusnya akan mengurangkan keupayaan komposit terhibrid ini untuk menyerap tenaga hentaman yang dikenakan. Struktur GNP yang berkeping-keping juga menjadikan GNP mudah untuk bertindan antara satu sama lain (Das et al. 2014) (Muhammad Razlan et al. 2017). Hal ini akan menyebabkan GNP kadang-kala tidak bertindak sebagai pengisi nano kerana aglomerasi yang terbentuk. Partikel GNP juga cenderung untuk membentuk agregat, ini menyukarkan penyebaran bahan di dalam matriks polimer kesan daripada tarikan daya van der Waals yang kuat (Valentini et al. 2016).

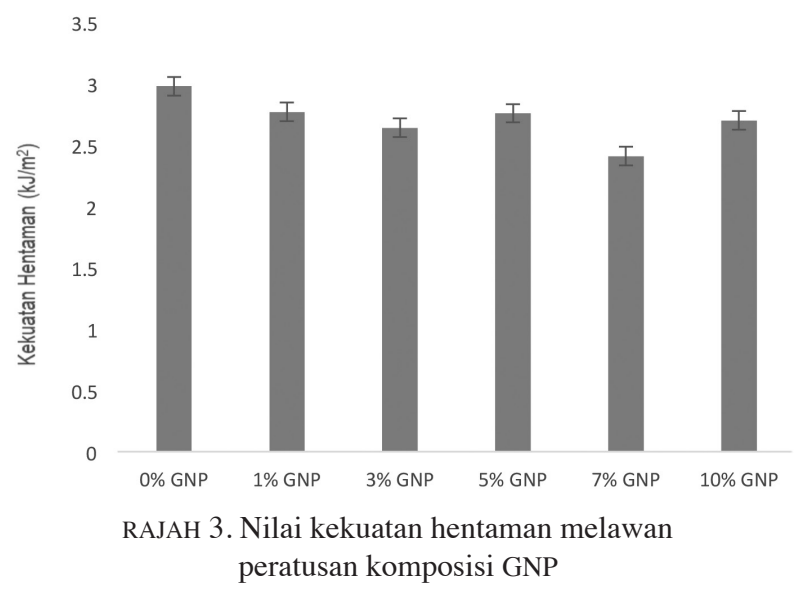

Jadual 1 menunjukkan keputusan analisis terma yang dilakukan dengan alat kalorimeter imbasan perbezaan (DSC). Penentuan kestabilan terma bahan adalah penting untuk menentukan tahap ketahanan sesuatu bahan terhadap haba yang dikenakan semasa pemprosesan dan juga pembuatan. Nilai $T_{g}$ tidak dapat dikesan pada termogram DSC kerana polimer yang digunakan ialah HDPE yang mempunyai $T_{g}$ yang sangat rendah. Penambahan GNP ke dalam komposit telah menyebabkan berlaku penurunan kecil nilai suhu penghaburan $(\mathrm{T})$ bahan. Penurunan ini mungkin disebabkan oleh sifat GNP yang lebih mudah mengalirkan haba berbanding dengan pengisi berselulosa seperti STF. Nilai $T_{c}$ komposit berpengisi juga adalah lebih rendah berbanding dengan nilai $\mathrm{T}_{\mathrm{c}}$ matriks. Ini 
JADUAL 1. Keputusan DSC yang dilakukan ke atas bahan

\begin{tabular}{lcc}
\hline Sampel & $\mathrm{T}_{\mathrm{c}}\left({ }^{\circ} \mathrm{C}\right)$ & $\mathrm{T}_{\mathrm{m}}\left({ }^{\circ} \mathrm{C}\right)$ \\
\hline NR/HDPE & 120.29 & 131.83 \\
STF/NR/HDPE/0\% GNP & 119.7 & 132.00 \\
STF/NR/HDPE/1\% GNP & 119.88 & 132.33 \\
STF/NR/HDPE/3\% GNP & 118.86 & 132.00 \\
STF/NR/HDPE/5\% GNP & 119.23 & 132.50 \\
STF/NR/HDPE/7\% GNP & 118.68 & 131.83 \\
STF/NR/HDPE/10\% GNP & 118.98 & 131.67 \\
\hline
\end{tabular}

kerana matriks bersifat lebih penebat dan pengaliran haba menjadi kurang berbanding dengan komposit berpengisi. Penambahan GNP meningkatkan nilai suhu peleburan $\left(\mathrm{T}_{\mathrm{m}}\right)$ tetapi pada komposisi GNP 7\% bt., nilai $\mathrm{T}_{\mathrm{m}}$ juga turut menunjukkan penurunan. Kehadiran GNP yang terlalu banyak telah mengganggu interaksi antara muka bahan dan menghalang proses resapan rantaian polimer untuk membentuk hablur. Oleh itu lebih banyak haba yang diperlukan untuk menggerakkan rantaian polimer untuk berada dalam keadaan yang lebih tersusun. Keputusan ini turut disokong oleh analisis XRD yang menunjukkan peningkatan peratus kehabluran bahan yang banyak pada komposisi $7 \%$ bt. GNP. Serakan GNP yang baik diperoleh pada komposisi $1 \%$ bt. Oleh itu, haba yang lebih banyak diperlukan untuk memutuskan ikatan rantaian polimer tersebut. Namun begitu, penambahan lebih banyak amaun GNP telah mengganggu interaksi antara bahan kerana partikel GNP tidak dapat terserak dengan baik di dalam komposit (rujuk Rajah 4 yang menunjukkan mikrograf FESEM bahan). Ini seterusnya mengakibatkan pengurangan jumlah pengaliran haba untuk memutuskan ikatan antara rantaian polimer terbabit. Oleh itu, nilai $T_{m}$ telah menunjukkan sedikit penurunan. Penambahan GNP sepatutnya meningkatkan sifat terma bahan. Namun begitu, penambahan GNP yang masih sedikit berbanding komposisi
STF dalam bahan tidak dapat meningkatkan sifat terma bahan kerana STF adalah sejenis pengisi berlignoselula yang mempunyai sifat penyalutan terma yang baik (Ramanaiah et al. 2014).

Jadual 2 menunjukkan keputusan ujian XRD yang telah dijalankan terhadap jumlah peratusan kehabluran bahan yang terbentuk daripada hasil adunan bahan komposit. Sampel yang digunakan dalam ujian ini adalah komposit yang mengandungi $20 \%$ tahap pengisian dengan komposisi GNP divariasikan antara $0-10 \%$. Daripada bentuk difraktogram sinar-X (Rajah 4) yang diperoleh dalam ujian ini, peratusan kehabluran dan keamorfusan bahan dapat ditentukan daripada puncak-puncak yang terhasil. Terdapat peningkatan kepada peratus kehabluran bahan apabila kandungan GNP ditingkatkan. Ini membuktikan bahawa GNP adalah agen penukleusan yang baik untuk meningkatkan kadar kehabluran bahan. Ini turut menyokong keputusan yang diperoleh daripada ujian tegangan tersebut.

JADUAL 2. Keputusan ujian XRD ke atas peratusan kehabluran bahan

\begin{tabular}{lc}
\hline Sampel & Kehabluran $(\%)$ \\
\hline STF/NR/HDPE/0\% GNP & 37.3 \\
STF/NR/HDPE/1\% GNP & 37.5 \\
STF/NR/HDPE/3\% GNP & 38.9 \\
STF/NR/HDPE/5\% GNP & 40.4 \\
STF/NR/HDPE/7\% GNP & 44.3 \\
STF/NR/HDPE/10\% GNP & 45.8 \\
\hline
\end{tabular}

Rajah 5 menunjukkan partikel GNP yang diperiksa dengan menggunakan mikroskop imbasan elekron pancaran medan (FESEM) pada pembesaran 50,000 kali. Jelas di situ menunjukkan partikel GNP yang berkepingkeping dan bertindan antara satu sama lain. Rajah 6 pula menunjukkan mikrograf daripada analisis FESEM ke atas

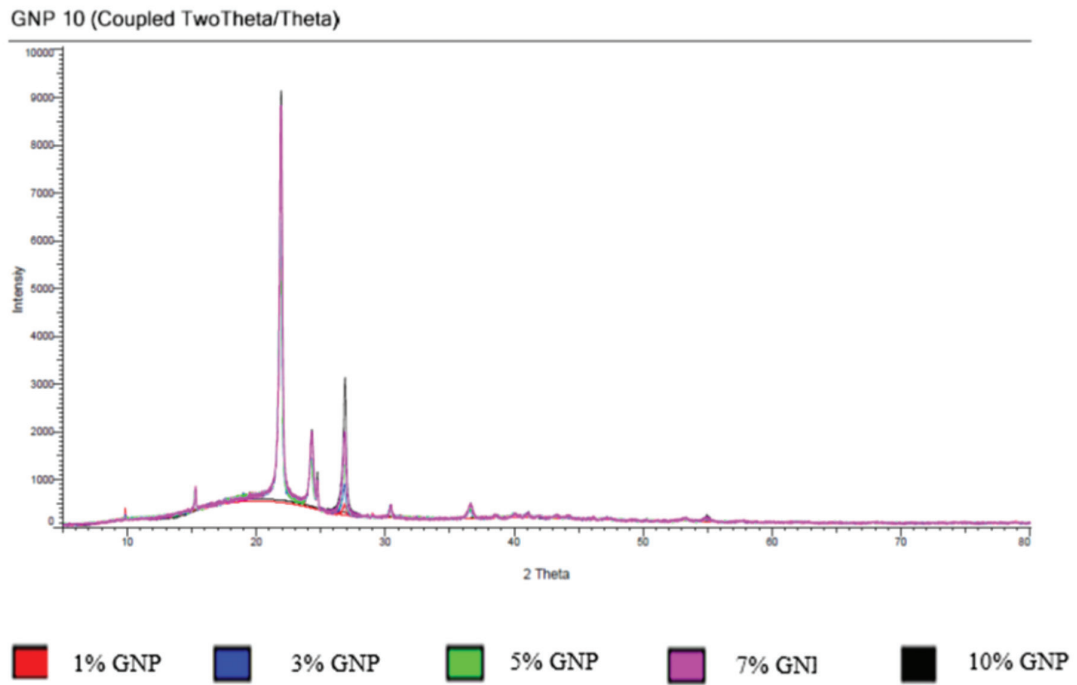

RAJAH 4. Difraktogram Sinar-X bagi komposit TSTF/NR/HDPE dengan penambahan GNP 


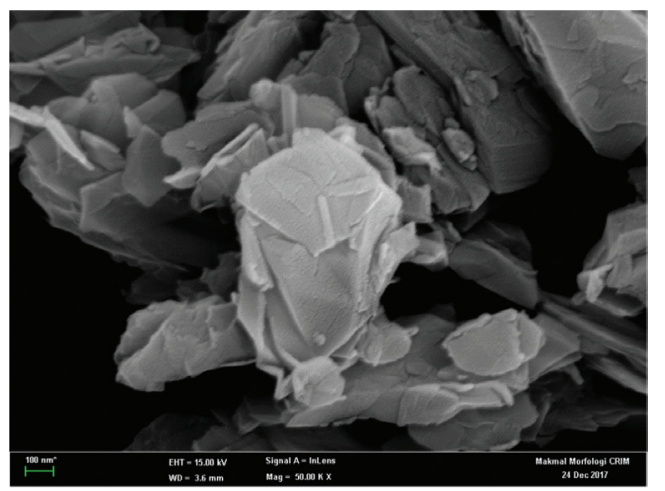

RAJAH 5. Mikrograf FESEM bagi partikel GNP dari pada pembesaran 50,000 kali
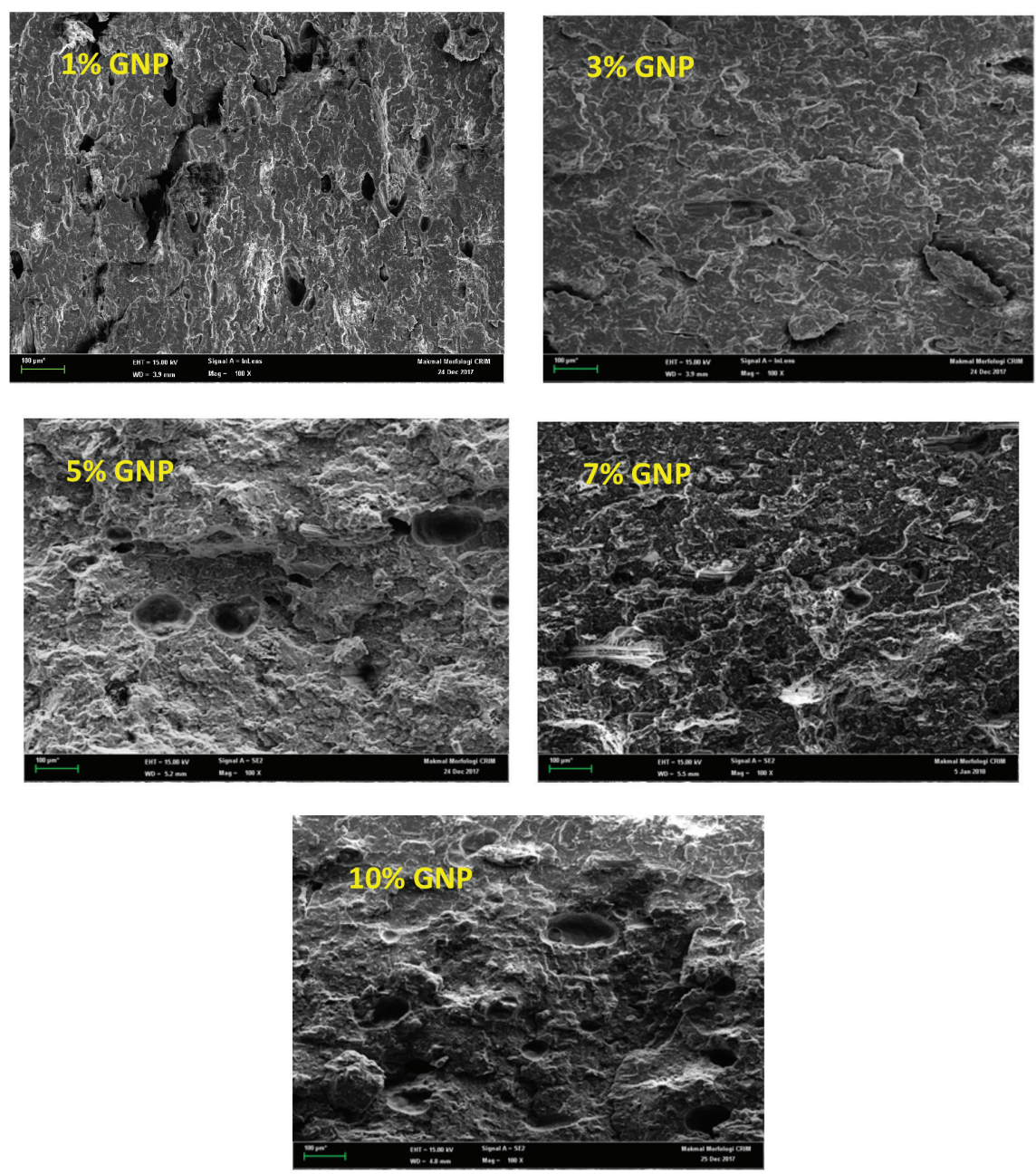

RAJAH 6. Mikrograf FESEM bagi penambahan GNP dari 1-10\%

komposit hibrid GNP/STF/NR/HDPE yang telah dilakukan. Permukaan patah sampel daripada ujian hentaman dengan pembesaran 100 kali telah digunakan dalam analisis ini untuk melihat taburan dan kehomogenan bahan. Komposisi $20 \%$ bt. STF dengan variasi $1-10 \%$ bt. GNP telah digunakan dalam analisis ini. Mikrograf FESEM menunjukkan pada komposisi 3-5\% bt. GNP, didapati memberikan campuran komposit yang lebih homogen dengan kesan terhadap matriks yang lebih rata. Kewujudan mikroliang juga didapati semakin berkurang dengan penambahan GNP ke dalam komposit. Interaksi yang baik antara bahan dapat diperhatikan daripada mikrograf FESEM yang diperoleh. Namun begitu, amaun GNP yang terlalu banyak di dalam bahan (melebihi 7\%) akan menyebabkan ketidakhomogenan dan aglomerasi bahan berlaku. 


\section{KeSIMPULAN}

Pengadunan komposit terhibrid GNP-STF-NR-HDPE dengan modifikasi GNP telah berjaya dilakukan. Penambahan GNP ke dalam komposit telah membantu meningkatkan beberapa sifat komposit, antaranya menjadikan komposit lebih tegar, meningkatkan keliatan bahan, mengurangkan kerapuhan bahan dan memberikan nilai tambah kepada sifat terma bahan.

\section{PENGHARGAAN}

Penghargaan ditujukan kepada Kementerian Pengajian Malaysia (KPM) untuk geran penyelidikan (FRGS/2/2014/ TK04/UKM/02/1), geran penyelidikan (FRGS-MRSA/1/2016/ STG07/UKM/01/1), Universiti Kebangsaan Malaysia (UKM), CRIM UKM dan Institut Penyelidikan dan Kemajuan Pertanian Malaysia (MARDI) yang membantu merealisasikan kajian ini.

\section{RUJUKAN}

Das, A., Boldt, R., Jurk, R., Jehnichen, D., Fischer, D., Werner Stockelhuber, R. \& Heinrich, G. 2014. Nano-scale morphological analysis of grapheme-rubber composites using 3D transmission electron microscopy. Royal Society of Chemistry 18: 9300-9307.

Faruk, O., Bledzki, A.K., Fink, H.P. \& Sain, M. 2012. Biocomposites reinforced with natural fibers: 2000-2010. Progress in Polymer Science 37: 1552-1596.

Frasca, D., Schulze, D., Wachtendorf, V., Huth, C. \& Schartel, B. 2015. Multifunctional multilayer graphene/elastomer nanocomposites. European Polymer Journal 71: 99-113.

Gao, Y., Picot, O.T., Bilotti, E. \& Peijs, T. 2017. Influence of filler size on the properties of poly(lactic acid) (PLA)/graphene nanoplatelet (GNP) nanocomposites. European Polymer Journal 86: 117-131.

Geng, Y., Wang, S.J. \& Kim, J.K. 2009. Preparation of graphite nanoplatelets and graphene sheets. Journal of Colloid and Interface Science 336: 592-598.

Hanafi, I., Nizam, J.M. \& Abdul Khalil, H.P.S. 2001. The effect of a compatibilizer on the mechanical properties and mass swell of white rice husk ash filled natural rubber/linear low density polyethylene blends. Polymer Testing 20(2): 125-133.

He, F., Mensitieri, G., Lavorgna, M., Luna, M.S., Filippone, G., Xia, H., Esposito, R. \& Scherillo, G. 2017. Tailoring gas permeation and dielectric properties of bromobutyl rubber - Graphene oxide nanocomposites by inducing an ordered nanofiller microstructure. Composites Part B 116: 361-368.

Idumah, C.I. \& Hassan, A. 2016. Characterization and preparation of conductive exfoliated graphene nanoplatelets kenaf fibre hybrid polypropylene composites. Synthetic Metals 212: 91-104.

Kang, H., Tang, Y., Yao, L. Yang, F., Fang, Q. \& Hui, D. 2017. Fabrication of graphene/natural rubber nanocomposites with high dynamic properties through convenient mechanical mixing. Composites Part B 112: 1-7.

Kanimozhi, M. 2011. Investigating the physical characteristics of Sansevieria trifasciata fibre. International Journal of Scientific and Research Publications 1(1): 1-4.

Kumar, K.H.G. \& Xavior, A.M. 2017. Processing and characterization of Al 6061 - graphene nanocomposites. Materials Today: Proceeding 4: 3308-3314.
Muhammad Razlan, Z., Muhammad Helmi, A.K., Hazizan, M.A. \& Mohd Zharif, M.T. 2017. Comparative study of graphene nanoparticle and multiwall carbon nanotube filled epoxy nanocomposites based on mechanical, thermal and dielectric properties. Composites Part B 119: 57-66.

Noor Intan, S.A., Sarani, Z., Kaco, H., Chia, C.H., Wang, C. \& Husna Shazwani, A. 2018. Physico-mechanical, chemical composition, thermal degradation and crystallinity of oil palm empty fruit bunch, kenaf and polypropylene fibres: A comparatives study. Sains Malaysiana 47(4): 839-851.

Nor Nabilla, K., Julie Elvyana, R., Norhamidi, M., Abu Bakar, S. \& Farhana, M.F. 2018. Pengoptimuman parameter sonikasi dan pengacauan magnetik bagi mendapatkan penyerakan sebati komposit kuprum-grafin berdasarkan sifat morfologi. Sains Malaysiana 47(5): 1039-1043.

Nurul Hidayah, I., Mohd Hafizi, M. \& Mariatti, J. 2018. Multiwalled carbon nanotubes/woven kenaf fabric-reinforced epoxy laminated composites. Sains Malaysiana 47(3): 563-569.

Nurzam Ezdiani, Z., Ishak, A., Wan Zarina, W.M. \& Azizah, B. 2018. Effects of fibre size on Sansevieria trifasciata/natural rubber/ high density polyethylene biocomposites. Malaysian Journal of Analytical Sciences 22(6): 1057-1064.

Ramanaiah, K., Ratna Prasad, A.V. \& Hema Chandra Reddy, K. 2013. Mechanical, thermophysical and fire properties of sansevieria fiber-reinforced polyester composites. Materials and Design 49: 986-991.

Sameer, B.R.K., Kumar, M.A., Murthy, V.N. \& Karthikeyan, N. 2015. Development of Sansevieria trifasciata-carbon fiber reinforced polymer hybrid nanocomposites. International Letters of Chemistry, Physics and Astronomy 50: 179-187.

Sathishkumar, T.P., Naveen, J. \& Satheeshkumar, S. 2014. Hybrid fiber reinforced polymer composites - A review. Journal of Reinforced Plastics and Composites 33: 454-471.

Shesmani, S., Ashori, A. \& Fashapoyeh, M.A. 2013. Wood plastic composite using graphene nanoplatelets. International Journal of Biological Macromolecules 58: 1-6.

Sreenivasan, V.S., Somasundaram, S., Ravindran, D., Manikandan, V. \& Narayanasamy, R. 2011. Microstructural, physicochemical and mechanical characterization of Sansevieria cylindrica fibres - an exploratory investigation. Materials and Design 32: 453-461.

Valentini, L., Bon, S.B, Machado, M.A.L., Verdejo, R., Pappalardo, L., Bolognini, A., Alvino, A., Borsini, S., Berardo, A. \& Pugno, N.M. 2016. Synergistic effect of graphene nanoplatelets and carbon black in multifunctional EPDM nanocomposites. Composites Science and Technology 128: $123-130$.

Ishak Ahmad \& Azizah Baharum*

Pusat Penyelidikan Polimer (PORCE)

Fakulti Sains dan Teknologi

Universiti Kebangsaan Malaysia

43600 UKM Bangi, Selangor Darul Ehsan

Malaysia

Nurzam Ezdiani Zakaria, Ishak Ahmad \& Azizah Baharum*

Pusat Pengajian Sains Kimia dan Teknologi Makanan

Fakulti Sains dan Teknologi

Universiti Kebangsaan Malaysia

43600 UKM Bangi, Selangor Darul Ehsan

Malaysia 
Nurzam Ezdiani Zakaria, Wan Nazri Wan Busu \&

Khairunnizah Hazila Khalid

Program Perekaan, Pemprosesan dan Pembungkusan Makanan

Pusat Penyelidikan Sains Teknologi Makanan

Institut Penyelidikan dan Kemajuan Pertanian Malaysia

Peti Surat 12301 Pejabat Pos Besar

50774 Kuala Lumpur

Malaysia
*Pengarang untuk surat-menyurat; email: azeiss@ukm.edu.my

Diserahkan: 19 September 2018

Diterima: $\quad 15$ Mac 2019 